\title{
Correlation of Intensity of Use of Social Media with The Level of Social Anxiety In Adolescents
}

\author{
Zahrul Khafida Silmi ${ }^{1)}$; Wiwin Renny Rachmawati2) Angga Sugiarto3); Tulus Puji Hastuti4) \\ zahrulkhafidasilmi21@gmail.com
}

\begin{abstract}
Background: Social media provides many positive impacts and ease of interaction, but not a few negative impacts, one of them was anxiety. Indonesia ranks 4th in the world in the used of social media with an average duration of usage for 8 hours 51 minutes every day. Though adolescence is an age where someone was very susceptible to anxiety. This anxiety if coupled with the high intensity of used of social media in adolescents was feared will have an effect on social interaction and cause anxiety to be higher and at risk of becoming social anxiety due to the lack of real communication to the social environment. The aims to find out the correlation between the intensity of the used of social media with the level of social anxiety in adolescents
\end{abstract}

Methods: This research used observational method with Cross Srectional design.

Results: Based on the results of the data analysis test, the value of $p=0.00(p<0.05)$ was obtained

Conclusion: There was a correlation between the intensity of the used of social media and social anxiety

Keyword : Social Media; Social Anxiety; Adolescent

\section{1,2) Poltekkes Kemenkes Semarang, Indonesia}

Jl. Tirtoagung, Pedalangan, Banyumanik

Background. Social media was an online media that supports social interaction as well as media that facilitates collaboration between users that produce content (used generated content) (Triyanto, 2019). The results of the "We Are Social" survey in 2017 conducted in Singapore showed that the population of Indonesia using social media reached 106 million out of a total population of 262 million. The highest activity of social media users in Indonesia is carried out by digitalnatives with a percentage of $62 \%$ used smartphones, $16 \%$ used computers, and $6 \%$ used tabs (Supratman, 2018).

Indonesia in terms of internet usage time was ranked fourth in the world with an average duration of usage for 8 hours 51 minutes every day. This usage was dominated by social activities in cyberspace with the percentage of users reaching $49 \%$ of the population with the duration of social media usage for 3 hours 23 minutes in one day(Tendhuha, 2018).

The intensity of the use of social media varies greatly for children, adolescents, and adults. However, if we look at the phenomenon that is happening right now, active users of social media are the children of late teens or early adults aged 18-24 years. Intensity can be said as a form of one's interest based on the quality and quantity designated by the individual, the intensity of the use of social media that has exceeded normal limits and carried out in daily life will also have an impact on communication between individuals in the real world(Taqwa, 2018).

Social media provides many positive impacts and ease of interaction, but not a few negative impacts caused(Tendhuha, 2018). Adolescent are often anxious when in front of people, not only in front of people they don't recognize, but also with people they know. Their anxiety arises from the fear of others' judgments about changes in their bodies and behavior (Prawoto, 2010).

Adolescents who have anxiety were often expressed in easily recognizable behaviors such as moody, nervous, easily offended, sleepless, irritable, and extraordinary sensitivity to the words or actions of others(Tendhuha, 2018). Such anxiety can be a social anxiety if adolescents are less sociable as explained that social anxiety is a persistent fear of one or more social situations related to performance, which makes individuals have to deal with strangers or face the possibility of being observed by people others are afraid that they will be humiliated or insulted(Akbar \& Faryansyah, 2015).

Adolescents who have anxiety were often expressed in easily recognizable behaviors 
such as moody, nervous, easily offended, sleepless, irritable, and extraordinary sensitivity to the words or actions of others(Tendhuha, 2018). Such anxiety can be a social anxiety if adolescents are less sociable as explained that social anxiety is a persistent fear of one or more social situations related to performance, which makes individuals have to deal with strangers or face the possibility of being observed by people others are afraid that they will be humiliated or insulted(Akbar \& Faryansyah, 2015).

Adolescence was a vulnerable period for someone to experience social anxiety. Data shows that the lifetime prevalence of individuals aged 13-18 years with social anxiety is $9.1 \%$. Other demographic data shows that in the age range of 13-14 years, as many as $7.7 \%$ of the population experience social anxiety social anxiety; $9.7 \%$ aged $15-16$ years; and $10.1 \%$ aged $17-18$ years(Akbar \& Faryansyah, 2015). The results of a preliminary study conducted by the author at Muhammadiyah 1 Muntilan High School Grade XI students all have social media accounts. The results of the social anxiety questionnaire to 210 grade $\mathrm{XI}$ students found 35 children experiencing high social anxiety, 137 children experiencing moderate social anxiety and 38 students experiencing low social anxiety.

Methods. This research used observational method with Cross Sectional research design with correlational approach. What was done using 210 social anxiety scale for adolescent (SAS-A) questionnaires to 210 students to determine the level of social anxiety. Then filtered using a random stratified sample. And as many as 145 samples were taken according to the Slovin formula and a drop-out added will be distributed Social Network Time Use-Scale (SONTUS) questionnaire to measure the intensity of the use of social media but if the number is sufficienthen only 138 students (calculation of the Slovin formula) will be used as research sample.
Result and discussion.

Table 1. Respondent caegories according to intensity of use of social media

\begin{tabular}{lll}
\hline \multicolumn{1}{c}{ Intensity } & Frequency & Percent \\
\hline Low & 35 & $25.4 \%$ \\
Moderate & 52 & $37.7 \%$ \\
High & 45 & $32.6 \%$ \\
Very high & 6 & $4.3 \%$ \\
Total & 138 & $100.0 \%$ \\
\hline
\end{tabular}

Table 2. Respondent categories according to level of social anxiety

\begin{tabular}{lcc}
\hline $\begin{array}{c}\text { Level of social } \\
\text { anxiety }\end{array}$ & Frequency & Percent \\
\hline Low & 26 & $18.8 \%$ \\
Moderate & 88 & $63.8 \%$ \\
High & 24 & $17.4 \%$ \\
Total & 138 & $100.0 \%$ \\
\hline
\end{tabular}

Table 3. Frequency distribution of intensity of use of social media with social anxiety levels

\begin{tabular}{llccc|c}
\hline & & \multicolumn{3}{c}{ Level of social anxiety } & \\
\cline { 3 - 5 } & & \multicolumn{3}{c}{ Mode- } \\
& Low & rate & High & Total \\
\hline \multirow{4}{*}{ Intensity } & Low & 24 & 10 & 1 & 35 \\
& Moderate & 2 & 49 & 1 & 52 \\
& High & 0 & 27 & 18 & 45 \\
& Very high & 0 & 2 & 4 & 6 \\
Total & & 26 & 88 & 24 & 138 \\
\hline
\end{tabular}

Table 4. The correlation of intensity of use of social media with social anxiety

\begin{tabular}{|c|c|c|c|c|}
\hline & Value & $\begin{array}{l}\text { Assympto } \\
\text { tic } \\
\text { Standard } \\
\text { Error }^{a}\end{array}$ & $\mathrm{~T}^{\mathrm{b}}$ & $\begin{array}{l}\mathrm{P} \\
\text { valu } \\
\mathrm{e}\end{array}$ \\
\hline Symmetric & .654 & .048 & $\begin{array}{c}10.09 \\
4\end{array}$ & .000 \\
\hline $\begin{array}{l}\text { SONTUS } \\
\text { Dependent }\end{array}$ & .752 & .048 & $\begin{array}{c}10.09 \\
4\end{array}$ & .000 \\
\hline $\begin{array}{l}\text { SASA } \\
\text { Dependent }\end{array}$ & .579 & .055 & $\begin{array}{c}10.09 \\
4\end{array}$ & .000 \\
\hline
\end{tabular}


The intensity of the use of social media has a positive correlation with the level of social anxiety which means the higher the intensity of the use of social media, the higher the level of social anxiety in adolescents.

Social media is very influential on the formation of adolescent social interaction. Another element that is not less important is how much media influences adolescent social interaction at school. Students who do more activities using social media, most of which are asked through the smartphone can experience a decrease in social interaction and can cause social anxiety. Some reasons are that social media makes communication easier and more practical than in the real world(Triyanto, 2019).

A study conducted in 1787 respondents aged 19-32 in the United States found that respondents who used social media for more than two hours per day had a tendency to feel isolated compared to those who used social media for less than 30 minutes per day(Primack et all, 2017).

Prastika (2018) states that anxieties can occur due to the use of the internet in which in the form of excessive social media, causing interpersonal issues such as introversion or social problems that even some users cannot communicate well in face-to-face situations. This makes them feel easier to communicate online because they feel safer and easier .

When a teenager has a high intensity in using social media it will make interpersonal communication or communication done directly with other people will be low, and vice versa when the intensity of using social media is low then the interpersonal communication is high. The use of high-intensity social media is based on data on the frequency of use $76 \%$ of subjects open social media more than 4 times per day and $68 \%$ spend their time to use social media more than 3 hours per day (Tenduha, 2018).

Azka (2009) found that $20 \%$ of internet users could be involved in one or more problems of self-neglect, avoiding others, being socially isolated, depressed, decreased work productivity due to a lot of social media, the emergence of problems in marital relations, sex addiction, online gambling, study failure because of not can regulate internet usage including checking and clicking behavior on an ongoing basis. The convenience provided by social media makes users social anxiety because social media users will always depend on it.

Prayoga and Akmal (2014) stated the correlation between social anxiety and social media dependence, where individuals who have social anxiety will use social media excessively to overcome the obstacles that exist in themselves. The results of the study indicate a negative impact between the excessive use of social media on the social life of the individual in terms of his interpersonal functions.

Other research which states that there is a correlation between social anxiety and social media dependency, namely research conducted by Soliha (2015) which states that social anxiety, depression, and loneliness significantly influence the emergence of dependence on social media. Someone with social anxiety tends to communicate online by presenting and portraying themselves as best they can in order to get positive impressions and images from other parties, sometimes even the impressions displayed do not match their original selves. This condition makes students who have social anxiety increasingly experience social media dependency or excessive use of social media.

This is in line with what was stated by Bessière, Kiesler, Kraut, and Boneva (2008) that there are differences in utilizing the internet and the impact produced between individuals who have social support and individuals who do not have social support in their environment. someone who is active in social media in real life will tend to utilize his social media for online communication in strengthening real world communication relationships without having to depend on social media, because its function is only to complete it.

According to Rudatiningtyas (2018) if someone spends more time using social media can cause teens to be exposed to negative emotions without realizing it, then if the intensity of using social media can also be a trigger for depression, social anxiety for adolescents, teens also only have less time to socialize with their peers in real life which causes teens to be unhappy with the real life they have.

The results of a Chotpitayasunondh \& Douglas study (2018) related to phubbing - the act of someone who only concentrates on his cellphone when in a social environment. Social media does offer a lot of convenience for 
communicating with many people anytime and anywhere just by staying silent and accessing it via a smartphone. When someone feels comfortable communicating through social media, that person will give high focus and only concentrate on what he is doing. The effect is when you're in a social environment, someone will ignore the people around him because they are busy accessing their cellphones, one of which is to communicate with other people or friends in cyberspace. Although direct communication is still carried out, the intensity will not be as long as when communicating through social media. As a result, the use of mobile phones has a significant negative impact on perceived communication quality and even impacts on the satisfaction of relationships between communicants and can lead to social gold because the person is not accustomed to communicating in real terms.

Conclusion and suggestions. There was a significant relationship between the intensity of the use of social media with the level of social anxiety in adolescents. Future studies can examine the negative effects of cell phone use in terms of intensity of use.

\section{References}

Akbar, Z., \& Faryansyah, R. (2015). Kecemasan Sosial Pada Remaja. (2008). IKRA-ITH HUMANIORA : Jurnal Sosial dan Humaniora. http://journals.upiyai.ac.id/index.php/ikraith-

humaniora/article/download/131/59

Azka, F., Firdaus, D. F., \& Kurniadewi, E. (2018). Kecemasan Sosial dan Ketergantungan Media Sosial pada Mahasiswa. $\quad 5, \quad 201-210$. https://doi.org/10.15575/psy.v5i2.3315

Bessière, K., Kiesler, S., Kraut, R., \& Boneva, B. S. (2008). Effects of internet use and social resources changes in depression. Information Communication and Society, 11(1), 47-70 doi.org/10.1080/13691180701858851

Chotpitayasunondh, V., \& Douglas, K.M, (2018). The effects of

social interaction. Diakses pada 24 September 2018, dari https://www. researchgate.net/publication/322682365 The effects of phubbing on so cial_interaction

Herman, F., Sambul, A. M., \& Paturusi, S. D. E. (2017). Pengukuran Skala Kecemasan Sosial pada Pengguna Media Sosial Berusia Dewasa Awal.

https://ejournal.unsrat.ac.id/index.php/inf ormatika/article/view/20195

Kriesniati, P., Yuniarti, D., \& Nohe, D. (2013). analisis korelasi somers'd pada data tingkat kenyamanan siswa-siswi smp plus melati samarinda. Retrieved from https://ojs3.unpatti.ac.id/index.php/barek eng/article/view/254

Kumalasari, F. (2012). Hubungan Antara Dukungan Sosial Dengan Penyesuaian Diri Remaja Di Panti Asuhan Latifah Nur Ahyani. 1(1). Retrieved from https://jurnal.umk.ac.id/index.php/PSI/arti cle/view/33

Merikengas, K. R., Jiang-ping He., Burstein, M., Swanson, S. A., Avenevoli, S., Cui, L., et. al. (2010). Lifetime prevalence of mental disorders in U.S. adolescents: results from National Comorbidity Survey ReplicationAdolescent Supplement (NCSA). Journal of American Academy of Child \& Adolescent Psychiatry, 49(10), 980-989.

Nainggolan, T. (2011). HUBUNGAN ANTARA KEPERCAYAAN DIRI DENGAN KECEMASAN SOSIAL PADA PENGGUNA NAPZA: Penelitian di Balai Kasih Sayang Parmadi Siwi Abstrak $B$. Tinjauan Pustaka. 161-174. Retrieved from

http://puslit.kemsos.go.id/upload/post/file s/129e0eda6a6486b083f43a47470b8e71 .pdf

Nasriati, R. (2010). kesehatan jiwa remaja. Retrieved from http://eprints.umpo.ac.id/1533/2/Artikel Kesehatan Jiwa Remaja.pdf

Prastika, D. (2018). hubungan smartphone addiction dengan kecemasan sosial remaja kelas XI IPA SMA N 1 Salaman. Retrieved from http://repository.poltekkessmg.ac.id/index.php?p=show_detail\&id= 15311\&keywords= 
Prawoto, Y. B. (2010). HUBUNGAN ANTARA KONSEP DIRI DENGAN KECEMASAN SOSIAL PADA REMAJA KELAS XI SMA KRISTEN 2 SURAKARTA (Vol. 9). https://doi.org/10.1558/jsrnc.v4il.24

Primack, B.A., ArielShensa, Jaime E.Sidani, Erin O.Whaite, Liu yiLin, DanielRosen, Jason B.Colditz, AnaRadovic, ElizabethMiller. (2017). Social Media Use and Perceived Social Isolation Among Young Adults in the U.S. American Journal of Preventive Medicine. https://doi.org/10.1016/j.amepre.2017.01. 010

Putri, wilga secsio ratsja, Nurwati, N., \& Budiarti, M. (2015). 7 pengaruh media sosial terhadap perilaku remaja. 3, 24424480. Retrieved from http://jurnal.unpad.ac.id/prosiding/article/ view/13625

Rakhmahappin, Y., \& Prabowo, A. (2014). kecemasan sosial kaum homoseksual gay dan lesbian. 02(02), 199-213. Retrieved from http://ejournal.umm.ac.id/index.php/jipt/ar ticle/view/1997

Rudatiningtyas, R. (2019) Hubungan Antara Intensitas Penggunaan Media Sosial dan subjective well being pada remaja. https://repository.usd.ac.id/33023/2/11 9114144_full.pdf
Soliha, S. F. (2015). Tingkat ketergantungan pengguna media sosial dan kecemasan sosial. Jurnal IImu Komunikasi, 4(1), 110. /doi.org/10.14710/INTERAKSI,4,1,1-10

Supratman, L. P. (2018). Penggunaan Media Sosial oleh Digital Native. Jurnal ILMU KOMUNIKASI, 15(1), 47-60. https://doi.org/10.24002/jik.v15i1.1243

Taqwa, mayvita innani. (2018). intensitas penggunaan media sosial instagram stories dengan kesehatan mental (universitas muhammadiyah malang). Retrieved from http://eprints.umm.ac.id/40564/

Tendhuha, A. naufi. (2018). Hubungan antara intensitas penggunaan media sosial dan komunikasi interpersonal pada remaja skripsi. Retrieved from http://eprints.umm.ac.id/43294/1/A\%27IN INDIYA NAUFI T_201410230311308.pdf

Tirtojiwo. (2012). social anxiety disorder (social fobia). 1-12. Retrieved from Tirtojiwo. (2012). social anxiety disorder (social fobia). 1-12.

Triyanto, A. (2019). PENGARUH INTENSITAS PENGGUNAAN MEDIA SOSIAL TERHADAP interaksi sosial tatap muka pada siswa kelas VIII. 628-636. http://journal.student.uny.ac.id. 